\title{
Response of eight Cucumis melo cultivars to salinity during germination and early vegetative growth
}

\author{
Pablo Botía, Micaela Carvajal*, Antonio Cerdá, Vicente Martínez \\ Departamento de Nutrición y Fisiología Vegetal, Centro de Edafología y Biología Aplicada del Segura, CSIC, \\ Apdo, Correos 4195, 30080 Murcia, Spain
}

(Received 30 September 1997 ; accepted 3 September 1998)

\begin{abstract}
In order to determine salt tolerance in eight varieties of Cucumis melo, two controlled environment experiments were carried out with seeds and seedlings. The tolerance study was carried out using the Van Genuchten equation which was found to have a very high level of fitting for melon. During the germination process, the most tolerant varieties were 'amarello' and 'amarillo oro' and during the early vegetative growth it was 'tendral terreno'. In general, there was no relationship between salt tolerance at the two stages of development. Salinity induced a decrease in the concentrations of $\mathrm{Ca}^{2+}, \mathrm{K}^{+}$and $\mathrm{Mg}^{2+}$ in the shoots, but only of $\mathrm{K}^{+}$ in the roots of all varieties. Phosphate concentration showed no significant changes either in the shoots or in the roots. Salt tolerance mechanism in Cucumis melo seems to be associated with a compartmentation process, since a correlation was found between $\mathrm{Na}^{+}$or $\mathrm{Cl}^{-}$uptake and tolerance. (C Inra/Elsevier, Paris.)
\end{abstract}

mineral composition / muskmelon / salinity / tolerance

Résumé - Réaction de huit cultivars de Cucumis melo à la salinité durant la germination et le début de la croissance végétative. Afin de déterminer la tolérance au sel de huit variétés de melon, deux expériences ont été faites en milieu contrôlé sur des graines et des plants. La tolérance au sel a été étudiée à l'aide de l'équation de Van Genuchten qui s'est trouvée convenir très bien pour le melon. Au cours du processus de germination les variétés les plus tolérantes au sel ont été « amarello » et « amarillo oro » et, pendant le début de la croissance végétative, la variété « tendral terreno ». La tolérance au sel n'est liée à aucun des deux stades de développement étudiés. La salinité a provoqué une diminution de la concentration en $\mathrm{Ca}^{2+}, \mathrm{K}^{+}$et $\mathrm{Mg}^{2+}$ dans les pousses mais, dans les racines de toutes les variétés, seule la concentration en $\mathrm{K}^{+}$a diminué. La

Communicated by Gérard Guyot (Avignon, France)

* Correspondence and reprints

Tel.: +34.968.21.57.17; fax: +34.968.26.66.13; e-mail: mcarvaja@natura.cebas.csic.es 
concentration en phosphate n'a montré de variation significative ni dans les pousses, ni dans les racines. Le mécanisme de la tolérance au sel chez Cucumis melo semble être associé à un processus de cloisonnement, puisqu'aucune relation n'a été trouvée entre l'absorption de $\mathrm{Na}^{+}$ou de $\mathrm{Cl}^{-}$et la tolérance. (C) Inra/Elsevier, Paris.)

\section{melon / composition minérale / salinité / tolérance}

\section{INTRODUCTION}

Melon is an important crop which is increasingly being cultivated using low-quality saline waters in semiarid regions. It has been widely studied how different cultivars vary from salt sensitive to moderately tolerant $[19,22,23]$. However, the sensitiveness or tolerance can differ according to the culture medium, the type of salinity and the plant growth stage $[19,26]$. Thus, relative tolerance during seed germination, seedling emergence and later stages of the plant may be different. It has been reported that melon is more tolerant to salinity during germination and emergence than during vegetative growth [22]. In any case, the evaluation of salt tolerance is complicated by the fact that growth rates are inherently different among cultivars, and seed viability differs depending upon seed age and the source of nutrient [31]. The response during germination has been reported to be more complex than during plant growth because it depends on the availability of storage compounds [7]. Some plants that have been classified as salt sensitive can germinate under high concentrations of $\mathrm{NaCl}[13,18]$. However, other tolerant species are more sensitive during germination [2, 12]. And, some halophyte species, which have their growth stimulated by salt, have even been reported to be salt sensitive during germination [11]. Consequently, the separate study of salt tolerance during germination or early and late growth stages is important for determining the limits of each variety in every development phase.

Exposure to $\mathrm{NaCl}$ salinity affects transport processes in the plant, the result of which can be an alteration of the nutritional status and tissue ion balance [14]. Salt stress inhibits the uptake and transport of $\mathrm{K}^{+}$[15], $\mathrm{Ca}^{2+}$ [16] and $\mathrm{P}$ [21] which influence plant growth. The nutritional imbalance has a greater or lesser degree of importance depending on the ambient conditions, the species and, within the same species, on the cultivars.

In this paper we studied eight common varieties of melon and compared their levels of tolerance to $\mathrm{NaCl}$ during the phases of germination and early growth. We also measured the concentrations of $\mathrm{Na}^{+}, \mathrm{K}^{+}, \mathrm{Ca}^{2+}, \mathrm{Mg}^{2+}, \mathrm{Cl}^{-}$and $\mathrm{P}$ in shoots and roots and tried to correlate them with salt tolerance in order to explain the differences among cultivars.

\section{MATERIALS AND METHODS}

\subsection{Germination assay}

Seeds of eight varieties of Cucumis melo L. (Galia, amarello, tendral terreno, piel de sapo hibrido, cantaloup americano, piel de sapo piñonet, amarillo oro and temprano rochet) were surface-sterilized in a $5 \%$ sodiumhypochlorite solution for $10 \mathrm{~min}$, washed with deionized water and disposed in Petri dishes (100 seeds per Petri dish) on a wet filter paper. The solutions used to moisten the filter paper contained $0.5 \mathrm{mM} \mathrm{CaSO}_{4}$ with either $0,30,60,90$ or $120 \mathrm{mM} \mathrm{NaCl}$. Seeds were germinated in an incubator at $29^{\circ} \mathrm{C}$ and a relative humidity of $90 \%$. Every day the germinated seeds were counted. Each treatment was replicated four times.

\subsection{Vegetative growth assay}

The seeds were germinated in vermiculite with 0.5 $\mathrm{mM} \mathrm{CaSO}$. The seedlings were disposed in containers of $15 \mathrm{~L} \mathrm{(} 30$ plants per container) with aerated Hoagland nutrient solution $\left(\mathrm{mmol} \mathrm{L}^{-1}\right): 6 \mathrm{KNO}_{3} ; 4 \mathrm{Ca}\left(\mathrm{NO}_{3}\right)_{2}, 1$ $\mathrm{Mg} \mathrm{SO}_{4}, 1 \mathrm{NH}_{4} \mathrm{H}_{2} \mathrm{PO}_{4}$, micronutrients $\left(\mu \mathrm{mol} \mathrm{L}^{-1}\right)$ were applied in the form of 20 Fe-EDTA, $25 \mathrm{H}_{3} \mathrm{BO}_{3}, 2$ $\mathrm{MnSO}_{4}, 2 \mathrm{ZnSO}_{4}, 0.5 \mathrm{CuSO}_{4}$ and $0.5 \mathrm{H}_{2} \mathrm{MoO}_{4}$. The con- 
tainers were transferred to a controlled environment chamber with a cycle of $16 \mathrm{~h}$ light and $8 \mathrm{~h}$ darkness at 27 and $18^{\circ} \mathrm{C}$, respectively. The relative humidity $(\mathrm{RH})$ was $60 \%$ (day) and $80 \%$ (night) and the photosynthetically

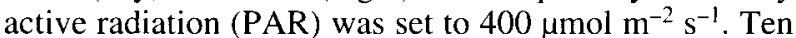
days after plantation, treatments of 0 (control), 30, 60, 90 and $120 \mathrm{mM} \mathrm{NaCl}$ (corresponding to $1.93,5.34,11.59$, 14.44 and $20.31 \mathrm{dS} \mathrm{m}^{-1}$, respectively) were applied to plants. Nutrient solution was renewed every $5 \mathrm{~d}$. At 16 and $29 \mathrm{~d}$ after sowing, samples of roots and shoots were taken in order to determine fresh and dry weights and mineral contents. Three plants constituted one sample and three samples per treatment were taken.

\subsection{Analysis of salt tolerance}

The growth data were analysed by the equation proposed by Van Genuchten and Hoffman [35]. They suggested a non-linear least-squares inversion method for evaluating the salt tolerance response of plants. The expression of the formulation considered was:

$$
\mathrm{Y}_{\mathrm{r}}=\mathrm{Y}_{\mathrm{m}} /\left[1+\left(\mathrm{c} / \mathrm{c}_{50}\right)^{\mathrm{p}}\right]
$$

where $\mathrm{Y}_{\mathrm{m}}$ is the relative growth rate under non-saline conditions $(0 \mathrm{mM} \mathrm{NaCl}$ treatment $), Y_{r}$ is the relative growth rate ( $\mathrm{g} \mathrm{f} . \mathrm{w} \cdot \mathrm{g}^{-1} \mathrm{~d}^{-1}$ ) at a given electric conductivity (c), $\mathrm{c}$ is the root zone electric conductivity $\left(\mathrm{dS} \mathrm{m} \mathrm{m}^{-1}\right.$ ), $\mathrm{c}_{50}$ is the electric conductivity at which growth is reduced by $50 \%$, and $\mathrm{p}$ is an empirical constant (generally $\mathrm{p}=3$ [34]).

\subsection{Mineral analysis}

Dried plant tissues $(0.1 \mathrm{~g})$ were digested in a concentrated nitric/perchloric acid $(2: 1, \mathrm{v} / \mathrm{v})$ mixture. Phosphorus was measured by the molybdenum-blue method described by Dickman and Bray [5]. Sodium and potassium concentrations were determined directly by atomic emission spectrometry and calcium and magnesium by atomic absorption spectrometry (Perkin Elmer500).

Chloride was extracted from $0.1 \mathrm{~g}$ ground material with $50 \mathrm{~mL}$ deionized water and measured by electrometric titration [9].

\subsection{Data analysis}

All the experiment were repeated at least three times and data were analysed calculating least significant differences (LSD).

\section{5. $\mathrm{Cl}^{-}$and $\mathrm{Na}^{+}$uptake}

$\mathrm{Cl}^{-}$and $\mathrm{Na}^{+}$uptake was calculated as specific absorption rate (SAR) since the experiment was carried out during the exponential growth phase, using the following equation [36]:

$$
\text { SAR }\left(\mu \mathrm{mol} \mathrm{mg} \mathrm{may}^{-1}\right)=1 / \mathrm{RDW} \partial \mathrm{M} / \partial \mathrm{T}
$$

where $\mathrm{M}$ is the ion content $(\mu \mathrm{mol}), \mathrm{t}$ is the time (days) and $\mathrm{R}$ the root dry weight $(\mathrm{mg})$, at two different periods.

\section{RESULTS}

Variations in the relative germination percentage (RGP) with time are represented in figure 1. It can be observed that there was a high variation in the dynamics of germination of the untreated (control) seeds of the different varieties. However, $100 \%$ of germination was reached by all varieties within $7 \mathrm{~d}$. The first variety to produce $100 \%$ germination was 'amarillo oro' ( $3 \mathrm{~d}$ ) followed by 'tendral terreno' and 'amarello' (4 d), and the last was 'cantaloup americano' (7 d). In general, $\mathrm{NaCl}$ reduced RGP, but 'amarello' and 'amarillo oro' were the least affected varieties. For the remaining varieties, the decrease in RGP became larger with increasing $\mathrm{NaCl}$ concentration. RGP values lower than $20 \%$ were observed for the $120 \mathrm{mM} \mathrm{NaCl}$ treatment. The variety 'cantaloup americano' was the most affected, showing minimal values at 90 and $120 \mathrm{mM}$ $\mathrm{NaCl}$.

An objective estimation of the salt tolerance of each variety studied was obtained by the Van Genuchten equation (see Material and methods). For each variety, the fit of the equation is represented in figure 2 (shoots) and figure 3 (roots). In all varieties, there was a high degree of significance in the fitting of shoot and root relative biomass data: the determination coefficients were between 0.59 (shoots of 'amarello') and 0.93 (shoots of 'piel de sapo piñonet' and roots of 'tendral terreno'). When the varieties were analysed individually, large differences in the $\mathrm{C}_{50}$ of shoots and roots were observed. The varieties with the highest and lowest $\mathrm{C}_{50}$ in shoots (figure 2) were 'tendral terreno' 

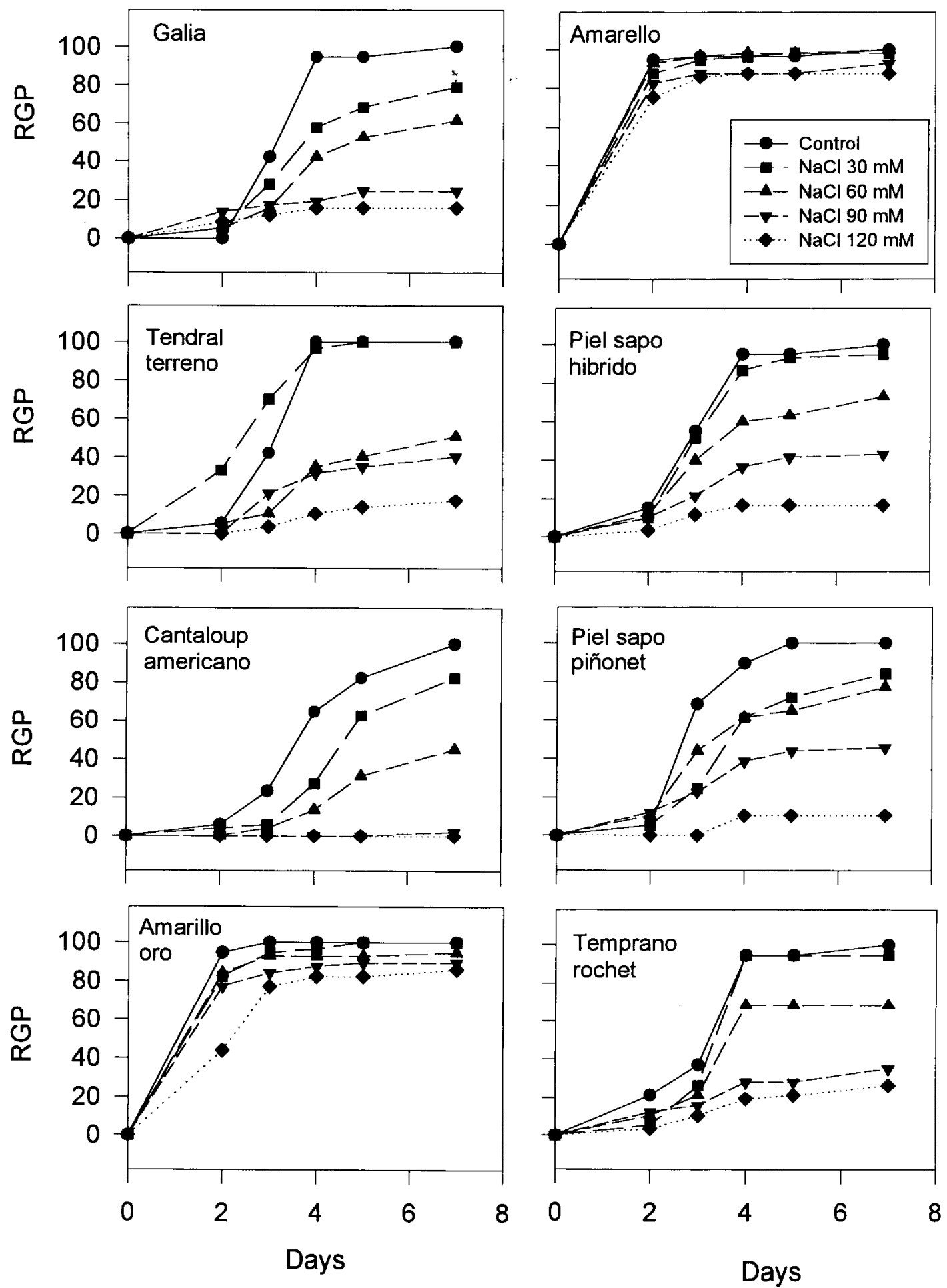

Figure 1. Relative germination percentage (RGP) of eight varieties of melon over $7 \mathrm{~d}$. The seeds were hydrated with $0.5 \mathrm{mM} \mathrm{CaSO}_{4}$ (control) and different concentrations of $\mathrm{NaCl}(30,60,90$ and $120 \mathrm{mM}) ;(n=4)$. 

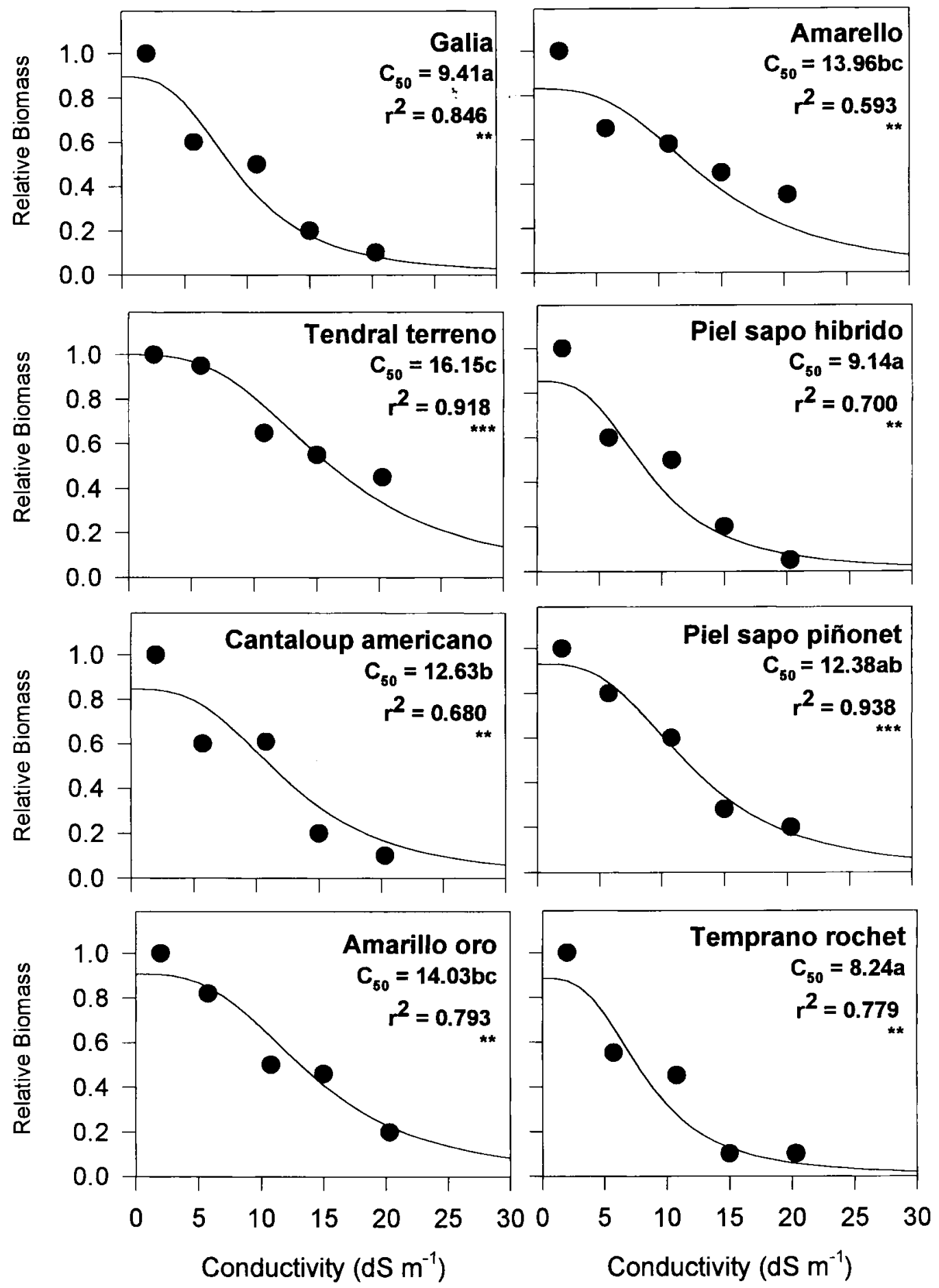

Figure 2. Effect of $\mathrm{NaCl}$ treatments on the shoot dry weight. The data are expressed as relative to control plants ( $0 \mathrm{mM} \mathrm{NaCl}$ added). The solid line represents the best fit obtained by the Van Genuchten equation. $*$ Significance level $<0.1, * *<0.05$ and $* * *<0.01$. $\mathrm{C}_{50}$ followed by different letter indicates significant differences at the $95 \%$ level of confidence or better. 

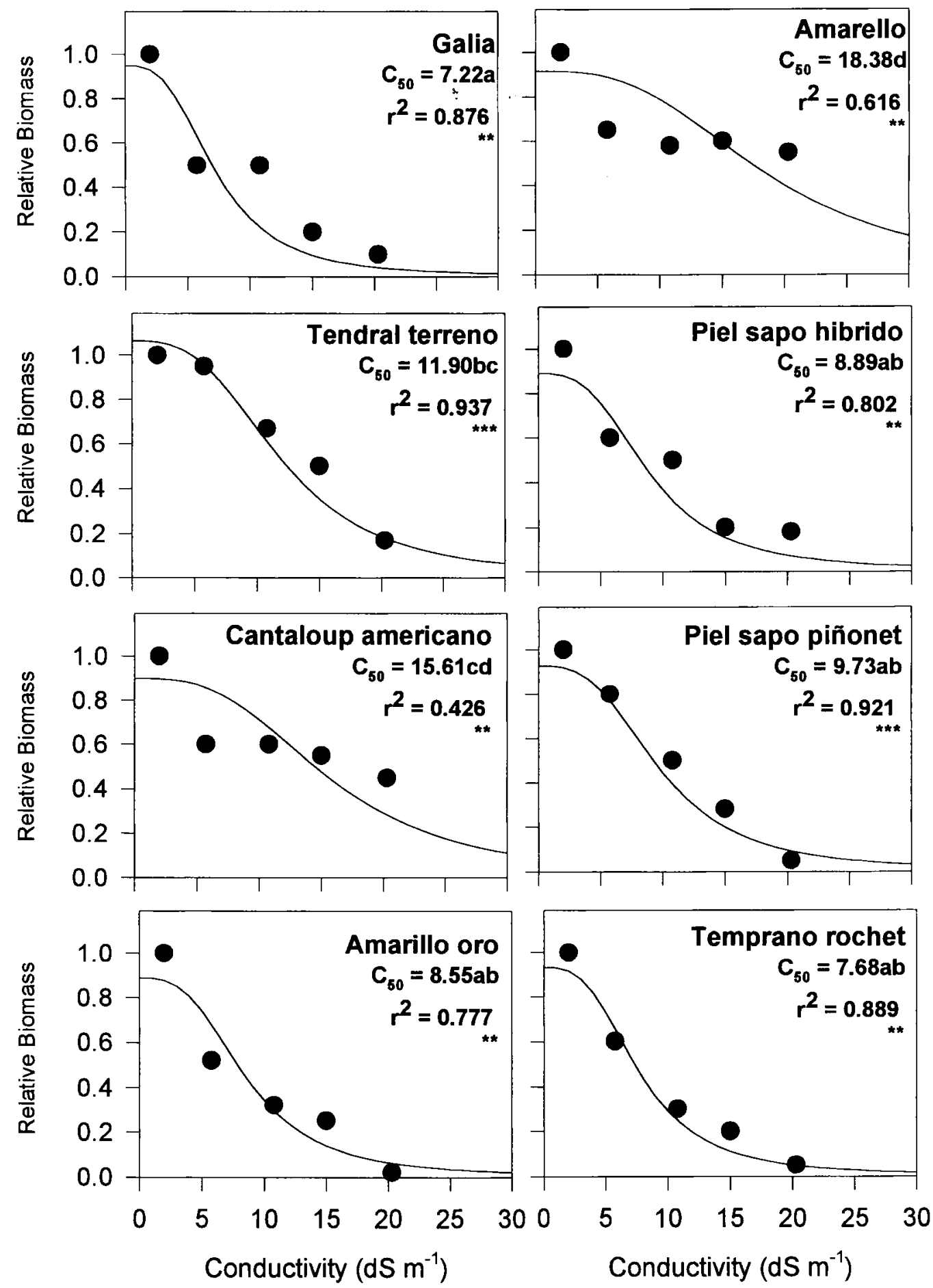

Figure 3. Effect of $\mathrm{NaCl}$ treatments on the root dry weight. The data are expressed as relative to control plants $(0 \mathrm{mM} \mathrm{NaCl}$ added $)$. The solid line represents the best fit obtained by the Van Genuchten equation. * Significance level $<0.1, * *<0.05$ and $* * *<0.01$. $\mathrm{C}_{50}$ followed by different letter indicates significant differences at the $95 \%$ level of confidence or better. 
(16.15) and 'temprano rochet' (8.24), respectively, whereas in roots (figure 3) they were 'amarrello' (18.38) and 'galia' (7.22). The range of variation of $\mathrm{C}_{50}$ in the roots was greater than in the shoots.

The changes in shoot and root ion concentrations in response to salinity are shown in figure 4 . Only average data are presented since ion concentration varied little among varieties at each $\mathrm{NaCl}$ concentration. The concentrations of $\mathrm{Na}^{+}$or $\mathrm{Cl}^{-}$in the shoots were significantly increased when higher $\mathrm{NaCl}$ concentrations were applied in the nutrient solution. However, in the roots, only a slight increase was observed after the $30 \mathrm{mM} \mathrm{NaCl}$ treatment but the concentration remained constant afterwards when higher $\mathrm{NaCl}$ concentrations in the nutrient solution were applied. Calcium concentration in shoots was significantly decreased with all $\mathrm{NaCl}$ treatments. However, no difference was found between the roots of treated and control plants $(0$ $\mathrm{mM} \mathrm{NaCl}$ ). The concentration of $\mathrm{K}^{+}$similarly decreased in shoots and roots after applying the $\mathrm{NaCl}$ treatments, but no significant differences were observed among the $\mathrm{NaCl}$ treatments. The concentration of $\mathrm{Mg}^{2+}$ in shoots decreased progressively at $30 \mathrm{mM}$ and $60 \mathrm{mM} \mathrm{NaCl}$, and remained constant at higher $\mathrm{NaCl}$ concentration, but no changes were observed in roots. No significant difference was found in $\mathrm{P}$ concentration either in shoots and roots or among treated plants.

The SAR of $\mathrm{Na}^{+}$and $\mathrm{Cl}^{-}$was calculated between 16 and $29 \mathrm{~d}$ and is shown in figure 5. A progressive increase in SAR of both ions was observed in all varieties studied when $\mathrm{NaCl}$ in the medium was increased from 30 to $90 \mathrm{mM}$. However, from 90 to $120 \mathrm{mM}$, SAR decreased reaching in most cases values similar to those obtained with $60 \mathrm{mM}$.

For each variety, the shoot $\mathrm{C}_{50}$ calculated by the Van Genuchten equation was linearly related to $\mathrm{Cl}^{-}$ or $\mathrm{Na}^{+} \mathrm{SAR}$ measured at $90 \mathrm{mM} \mathrm{NaCl}$ (figure 6). The correlation between $\mathrm{Cl}^{-} \mathrm{SAR}$ and $\mathrm{C}_{50}$ was highly significant $(P<0.05)$ as shown in figure $6 b$. Nevertheless, this correlation was lower in the case of $\mathrm{Na}^{+}(P<0.1$; figure $6 a)$. No correlation was found for the other analysed ions (data not shown).

\section{DISCUSSION}

The germination process depends on the capacity of the seeds to absorb water [1]. This capacity can be altered if the osmotic potential of the external solution increases and if the enzyme and hormone levels in the seeds change as a consequence of the toxic effect produced by high concentrations of $\mathrm{Na}^{+}$or $\mathrm{Cl}^{-}$. Salinity may affect germination in two different ways, by either reducing the percentage of germination owing to inhibition or simply causing a delay immediately after applying the treatments. These two effects were observed in our experiments. Some treatments such as 30 and $60 \mathrm{mM} \mathrm{NaCl}$ produced a delay in RGP of almost all the varieties, the $100 \%$ germination being reached some days later than that of the control. However, 90 and $120 \mathrm{mM} \mathrm{NaCl}$ usually caused an inhibition of RGP either total (cantaloup americano), or partial from 20 to $80 \%$ (the rest of the varieties). This inhibition can be reversible [31] which implies that there is no damage to the structures of the seeds and the normal process may occur when the control treatment is added. This protection mechanism is very common in wild-type species, where seeds can remain in a latent stage under saline conditions [33].

In an attempt to fit a general response function to all salt tolerance data, Maas and Hoffman [17] published a comprehensive analysis based upon an extensive review of the literature. They found that most crops tolerate soil salinity up to a threshold level, above which yields show an approximately linear decrease. In some cases, subjective judgement was required to include or exclude data from the analysis. The method we have used in this paper allows a convenient analysis of the data by coupling a salt tolerance model with a least squares optimization procedure. In our experiments, this model proposed by Van Genuchten and Hoffman produces highly significant fittings for the early growth values of all varieties studied $(P<0.05)$ which implies that it could be a good method for determining the tolerance of melon plants to salinity. Several studies demonstrated that, in general, there is no relationship between the tolerance during germination and 

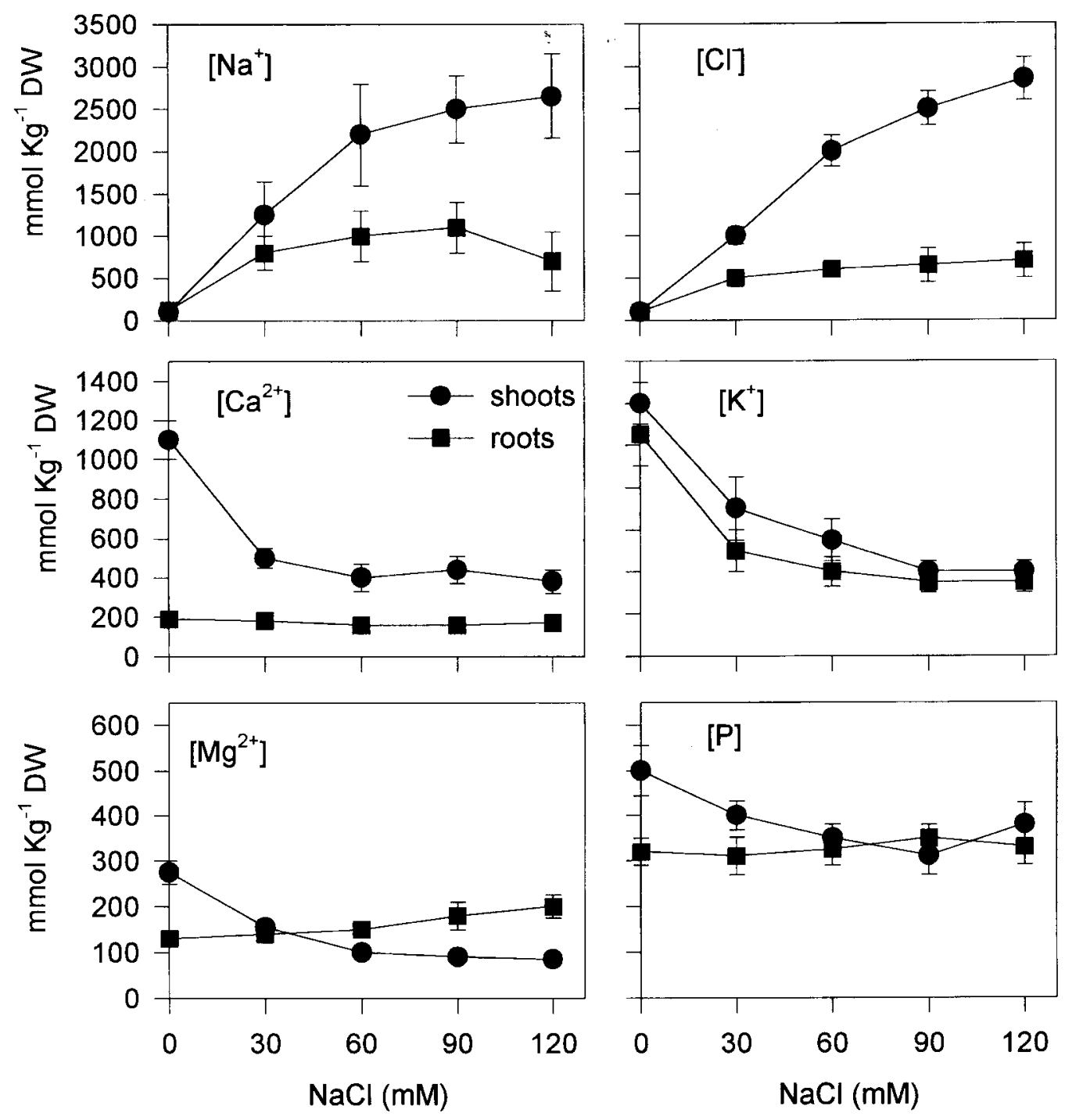

Figure 4. Effect of $\mathrm{NaCl}$ treatments on the nutrient concentration in the shoots and the roots of eight varieties of melon plants. Each point is the mean of results \pm SE obtained from all varieties and three replicates per variety.

growth period of melon $[6,26]$. However, the study of tolerance during germination and emergence is important for establishing the limit for salt concentrations and the germination delays for each variety. From our results, the most tolerant seeds were 'amarrello' and 'amarrillo oro'. For shoot growth of seedlings, the variety showing the highest $\mathrm{C}_{50}$ was 'tendral terreno' and for roots it was 'amarello'. The differences observed between tolerance of shoots and roots of each variety could be due to water availability after the osmotic adjustment since no relationship between tolerance and nutrient concentration appeared in our study. The separate study of the shoot and root tolerance is interesting because of the different behaviour of both parts under salt conditions. Although 'amarello' and 'tendral terreno' can be classified amongst the most tolerant cultivars, a factor which has to be taken 

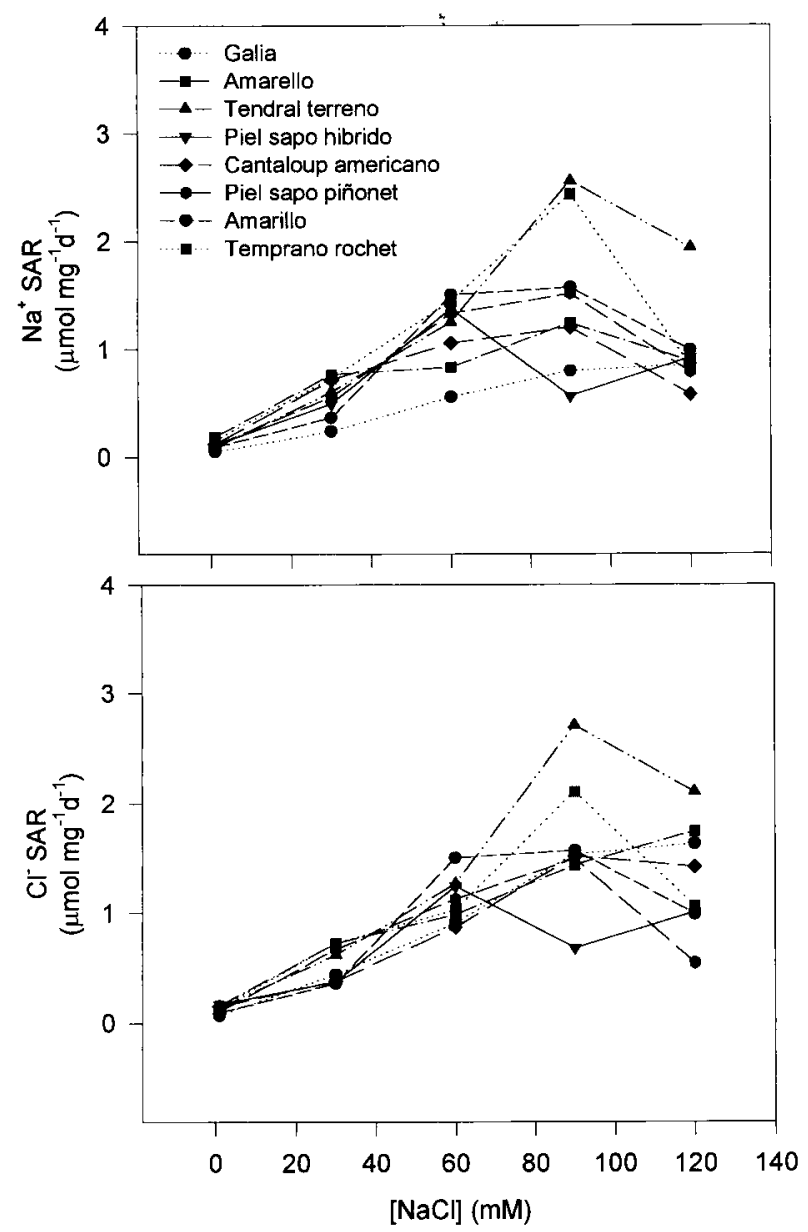

Figure 5. Effect of $\mathrm{NaCl}$ treatments on $\mathrm{Na}^{+}$and $\mathrm{Cl}^{-}$specific absorption rates (SAR) of the eight varieties of melon. SARs are the mean values calculated between 16 and $29 \mathrm{~d}$ of growth.

into account is the growth conditions. In our study, the germination and growth data were obtained from experiments under controlled environments. Some changes in tolerance are expected to occur when the experiments are carried out in field conditions since plants show different degrees of resistance to changes in climate. The results of this paper, however, could be very interesting for breeding experiments with Cucumis melo in order to choose the most tolerant varieties, because a good correlation between early and late growth has been established for this crop [24].
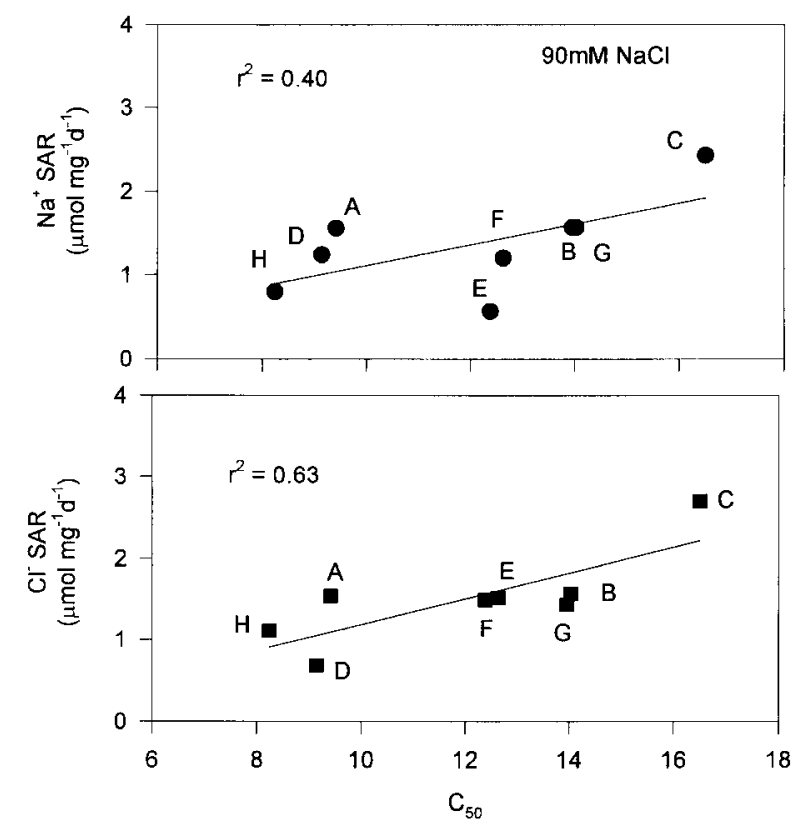

Figure 6. Correlations between $\mathrm{Na}^{+}$or $\mathrm{Cl}^{-} \mathrm{SARs}$ and $\mathrm{NaCl}$ tolerance (expressed as $C_{50}$ ) of the eight varieties of melon plants (A: Galia; B: amarello; C: tendral terreno; D: piel de sapo hibrido; E: cantaloup americano; F: piel de sapo piñonet; $G$ : amarillo oro; and $\mathrm{H}$ : temprano rochet) grown under $90 \mathrm{mM} \mathrm{NaCl}$.

The decrease in $\mathrm{K}^{+}$concentration found in Cucumis melo plants grown under saline conditions has been previously described and explained in terms of the competitive uptake between $\mathrm{Na}^{+}$and $\mathrm{K}^{+}$[20]. In our experiments, the saline stress reduced the $\mathrm{Ca}^{2+}$ and $\mathrm{Mg}^{2+}$ concentrations only in the shoots, while in the roots they remained constant. This effect has been reported in other species such as Helianthus annuus [28] or Solanum melongena [29]. Lynch and Läuchli [16] proposed that the decrease in the concentration of these cations in the shoots may be related to the reduced $\mathrm{Ca}^{2+}$ release into the root xylem, possibly by affecting the cation active loading in the xylem vessels. Cramer et al. [4] also found a significant interaction between $\mathrm{Na}^{+}$ and $\mathrm{Ca}^{2+}$. However, Savvas and Lenz [29] suggested that a higher proportion of lignified root mass indicates less protoplasm and more cell walls and therefore more sites of indiffusible anions which 
are saturated by $\mathrm{Ca}^{2+}$ and $\mathrm{Mg}^{2+}$. That could explain the fact that in our melon plants the concentration of both cations was not altered after increasing salinity from 30 to $120 \mathrm{mM}$.

It is usually predicted that salt sensitivity is associated with poor control of $\mathrm{Na}^{+}$or $\mathrm{Cl}^{-}$transport from root to shoot [10]. But the most common evidence is the correlation found between the exclusion of $\mathrm{Na}^{+}$or $\mathrm{Cl}^{-}$and the salt tolerance [27,30, 32]. In our plants, the fact that there is no inverse relationship between $\mathrm{Na}^{+}$and $\mathrm{Cl}^{-} \mathrm{SAR}$ and salt tolerance, has led us to think that there is no exclusion mechanism for salt tolerance in this crop [8]. Furthermore, this significant correlation found between shoot $\mathrm{C}_{50}$ and $\mathrm{Cl}^{-}$or $\mathrm{Na}^{+} \mathrm{SAR}$ suggests that the implication of these ions in any aspect of the tolerance of melon could be related to compartmentation. Little is known about the compartmentation of $\mathrm{Cl}^{-}$[3]. However, some approaches give $\mathrm{Cl}^{-}$ a role in the salt tolerance processes [25]. Recent findings (V. Martínez, unpublished results) in which $\mathrm{Cl}^{-}$is accumulated in stems rather than in leaves of tolerant varieties of melon suggest that $\mathrm{Cl}^{-}$ might have a role in the tolerance process of melon plants and that a compartmentation at organ level is likely. High tolerance is based mainly on the inclusion of salts and their use in turgor maintenance. These inclusions and the partitioning of $\mathrm{Na}^{+}$and $\mathrm{Cl}^{-}$ into various organs and tissues are of major importance. This holds true in the case of partitioning between old and young leaves, leaf sheath and leaf blades, and vegetative and reproductive organs. However, this should be investigated further in melon in order to interpret its mechanism of relative salt tolerance.

Therefore, the overall conclusion of this study is that during the germination process, the most tolerant varieties were 'amarello' and 'amarillo oro' and during the early vegetative growth it was 'tendral terreno'. We believe that salt tolerance has no relation to the concentrations of $\mathrm{Ca}^{2+}, \mathrm{K}^{+}, \mathrm{Mg}^{2+}, \mathrm{K}^{+}$and $\mathrm{P}$ in the shoots or in the roots. However, the mechanism of salt tolerance in Cucumis melo seems to be associated with a compartmentation process.

\section{REFERENCES}

[1] Al-Niemi T.S., Campbell W.F., Rumbaugh M.D., Response of alfalfa cultivars to salinity during germination and post-germination growth, Crop Sci. 32 (1992) 976-980.

[2] Ayers D.A., Hayward H.E., A method for measuring the effects of soil salinity on seed germination with observations on several crop plants, Soil Sci. Soc. Am. Proc. 13 (1948) 224-226.

[3] Binzel L.M., Hess F.D., Bressa R.A., Hasegawa P.M., Intracellular compartmentation of ions on salt adapted tobacco cells, Plant Physiol. 86 (1988) 607-614.

[4] Cramer G.R., Epstein E., Läuchli A., Na-Ca interaction in barley seedlings: relationship to ion transport and growth, Plant Cell Environ. 12 (1989) 551-558.

[5] Dickman S.R., Bray R.H., Colorimetric determinations of phosphate, Ind. Eng. Chem. Anal. Ed. 12 (1940) 665-668.

[6] Fraņois L.E., Salinity effect on germination, growth and yield of two squash cultivars, Hortscience 20 (1985) 1102-1104.

[7] Gonzalez M.C., Sanchez D.M., Aparicio T.P., Chaves S.M., The effect of $\mathrm{NaCl}$ and water stress on germination and $\alpha$-galactosidase activity in germinated seed of Medicago sativa, Trifolium repens and Trifolium brachycalycium, J. Plant Physiol. 119 (1985) 317-326.

[8] Greenway H., Munns R., Mechanism of salt tolerance in nonhalophytes, Annu. Rev. Plant Physiol. 31 (1980) 149-190.

[9] Guilliam M.G., Rapid measurement of chlorine in plant materials, Soil Sci. Soc. Am. Proc. 35 (1971) 512-513.

[10] Hajibagheri M.A., Harvey D.M.R., Flowers T.J. Quantitative ion distribution within root cells of salt-sensitive and salt-tolerant maize varieties, New Phytol. 105 (1987) 367-379.

[11] Keiffer C.H., Ungar I.A., The effect of extended exposure to hypersaline conditions on the germination of five inland halophyte species, Am. J. Bot. 84 (1997) 104-111.

[12] Kent L.M., Läuchli A., Germination and seedling growth of cotton: salinity-calcium interactions, Plant Cell Environ. 8 (1985) 155-159.

[13] Kurt E., Jensen A., Epstein E. Resistance of fully imbibed tomato seeds to very high salinities, Plant Cell Environ. 9 (1986) 667-676. 
[14] Läuchli A., Epstein E., Plant responses to saline and sodic conditions, in: Tanji K.K. (Ed.), Am. Soc. Civil Eng, New York, 1990, pp. 113-137.

[15] Lynch J., Läuchli A., Potassium transport in saltstressed barley roots, Planta 161 (1984) 295-301.

[16] Lynch J., Läuchli A., Salt stress disturbs the calcium nutrition in barley (Hordeum vulgare L.), New Phytol. 99 (1985) 345-354.

[17] Maas E.V., Hoffman G.J., Crop salt tolerance current assessment, J. Irrig. Dain Division ASCE 103 (1977) 115-134.

[18] Maas E.V., Hoffman G.J., Chaba G.D., Poss J.A., Shannon M.C., Salt sensitivity of com at various growth stages, Irrig. Sci. 4 (1983) 45-57.

[19] Mangal J.L., Hooda P.S., Lal S., Salt tolerance of five muskmelon cultivars, J. Agric. Sci. 110 (1988) 641-643.

[20] Marschner H., Kuiper P.J.C., Klin A., Genotypic differences in the response of sugar beet plants to replacement of potassium by sodium, Physiol. Plant. 83 (1981) 627-632.

[21] Martínez V., Bernstein N., Läuchli A., Saltinduced inhibition of phosphorus transport in lettuce plants, Physiol. Plant. 97 (1996) 118-122.

[22] Mendlinger S., Pasternak D., Effect of time of salinization on flowering, yield and fruit quality factors in melon, Cucumis melo L, J. Hortsci. 67 (1992) $529-534$.

[23] Mendlinger S., Pasternak D., Screening for salt tolerance in melons, Hortsci. 27 (1992) 905-907.

[24] Nerson H., Paris H.S., Effects of salinity on germination, seedling growth and yield of melons, Irrig. Sci. 5 (1984) 265-273.

[25] Niu X., Bressa R.A., Hasegawa P.M., Pardo J.M. Homeostasis in $\mathrm{NaCl}$ stress environments, Plant Physiol. 109 (1995) 735-742.
[26] Nukaya A., Masui M., Ishida A., Salt tolerance of muskmelons grown in different salinity soils, J. Jpn. Soc. Hortic. Sci. 48 (1980) 468-474.

[27] Omielan J.A., Epstein E., Dvorak J., Salt tolerance and ionic relations of wheat as affected by individual chromosomes of salt-tolerant Lophopyrum elongatum, Genome 34 (1991) 961-974.

[28] Sanchez-Raya A.J., Delgado I.C., Mineral nutrient transport by sunflower seedling grown under saline conditions (NaCl), J. Plant Nutr. 19 (1996) 1463-1475.

[29] Savvas D., Lenz F., Influence of $\mathrm{NaCl}$ concentration on the nutrient solution on mineral composition of eggplants grown in sand culture, Angew. Bot. 70 (1996) 124-127.

[30] Schachtman D.P., Munns R., Whitecross M.I., Variations in sodium exclusion and salt tolerance in Triticum tauchii, Crop Sci. 31 (1991) 992-997.

[31] Shannon M., Bohn G., McCreight J., Salt tolerance among muskmelon genotypes during seed emergence and seedling growth, Hortic. Sci. 19 (1984) $828-8330$.

[32] Subbarao G.B., Johansen C., Jana M.K., KumarRao J.V.D.K., Physiological basis of differences in salinity tolerance of pigeonpea and its related wild species, J. Plant Physiol. 137 (1990) 64-71.

[33] Ungar I.A., Halophyte seed germination, Bot. Rev. 44 (1978) 233-264.

[34] Van Genuchten M.T., Analyzing crop salt tolerance data: Model description and user's manual, USDAARS, USSL, Research Rep. 120, Washington DC, 1983.

[35] Van Genuchten M.T., Hoffman G.J., Analysis of crop salt tolerance data, in: Shalhevet (Ed.), Soil Salinity Under Irrigation: Processes and Management, SpringerVerlag, Berlin, 1984, pp. 258-271.

[36] William R.F., The physiology of plant growth with special reference to the concept of net assimilation rate, Ann. Bot. 10 (1946) 41-72. 